To the Editors: I would have welcomed Professor Lisa Anderson's critical review

\section{THE AGRICULTUAAL LIFE}

To the Editors: After a long day, I was reading Sudhir Sen's commentary on Professor Galbraith's World Food Day address (Worldview, May), and I stumbled over a tripwire. The alarm so activated grew louder as I read on, so I went back and it happened again. What was it that, persistently, the mind of this Midwestern livestock producer and grain farmer would not accept? Ah, there it is! (Forgive my paraphrasing.)

"It is a universal practice in the industrialized countries to ensure the agricultural producer a stable and predictable return on effort and investment."

A policy that ensures return on effort and investment? Where? Quick, we must move!

Pinch me, I'm dreaming!

No, wait, he goes on

"But many new nations, by contrast, keep the agricultural prices low as a concession to urban workers and dwellers or because it is politically expedient."

Of course, in this postindustrial age, the writer is correctly including the United States with the new nations. The clamor of the alarm dies away and I read on.

A pleasant article (Galbraithian economics and I have long been on speaking termsone way, of course), but there is still a faint ringing echo. Come out to the farm one day, Sudhir Sen. We will take tea and time with some of those around here who walk behind the ploughs.

Stable and predictable retum on effort and investment indeed!

John Essame

Belview, Minn

\section{Sudhir Sen responds:}

John Essame "stumbled on a tripwire" for very good reason. After all, in recent years the American farmer has seen anything but stable and predictable return on effort and investment, and in most cases through no fault of his own. Budget Director David Stockman, the financial wizard engrossed in his budget-pruning process, missed this elementary point. The Wunderkind fully deserved-and received-a refreshing dose of scolding administered by his down-toearth mother.

Stockman's error was, indeed, elementary. For a farmer's life is a continuous battle against the elements-droughts, floods, storms, frost, and snow - and also against pests and pathogens. In addition, he is mercilessly exposed to the ups and downs of the marketplace. The price swings can be quite violent, as in recent years. Again, like the vagaries of weather, they stem from forces over which the farmer has no control. Only when he is adequately protected against these twin enemies can he effectively fulfill his twin functions that are so vital for a nation: first, to produce food and fiber in optimum quantities and at reasonable cost; and, second, to conserve soil, build up its fertility, enhance the asset value of the farm, and maintain it in shipshape condition for the benefit of future generations.

This is the rationale behind the farm support system. And who can deny that, born in the dark days of the Great Depression, it has served the American farmer and the American economy as a whole wonderfully well? It has spread prosperity through the countryside, which, in turn, has provided essential underpinnings for national prosperity

Now we all know that a farm support system-like everything else designed by mortals, especially in their political incarnation-can be abused, misused, at times even negated in practice. We need only recall how easily it becomes a plaything of electoral politics at home or a hostage to diplomatic wrangling abroad. Worse still are the macroeconomic follies of the last five years: huge budget deficits, tight money, oppressively high interest rates, the bloated dollar, and record trade deficits. Here one must separate wheat from chaff. It is these follies that are the primary cause of the farmer's toes today, not the principle of price support

The story of Third World farmers is entirely different. With few exceptions they still languish in a medieval world dominated by feudal landlords. They are not only at the mercy of weather, pests and insects, and so-called market forces but are exploited by their own masters. There is no farm support program to protect them; instead, farmers are used to provide urban support! This is the taproot of the poverty and hunger that are exploding in the Third World today!

So there is a lot to talk about, John Essame. How thoughtful of you, and how kind, to invite me to tea with you and your friends who walk behind the plough. Nothing could give me greater pleasure than to revisit American farms and chat with people like you. May I take a rain check on your invitation? of my book, The Islamic Conception of Justice (Worldview, April), were it fair and objective. Since subjective views often distort scholarlay endeavors and create misunderstanding, may I offer the following remarks.

First, in reviewing both my book and Professor Bernard Lewis's The Jews of Is lam, Professor Andersan gives the impression that the two books deal essentially with the same subject and that, of the two, my book is "the more general and less satisfying." Professor Lewis's book, as a matter of fact, is a general study of the Jews in Islam, and, as a historian, he applies the historical method to his subject. By contrast, my book deals with "justice" as a central concept in the Islamic public order and examines in detail the ideas and doctrines of Muslim thinkers about justice with a view to reconstructing an Islamic theory of justice. Committed to the two disciplines of law and political science, I have applied the methods of the two disciplines in theory and practice in relevance to conditions. I have called this method "empirical idealism," and I explained it in a section of my book entitled "scope and method of this study." Thus, by comparing my book with the other under review without indicating the differences, the reviewer has painted a distorted picture of the scope and method of my book.

Second, Professor Anderson describes my book as "a history of ideas" and "abstract doctrines," without reference to "social conditions or historical circumstances." She seems to have missed the whole purpose of the book-that it is not "a history of ideas" but an inquiry into a set of notion about justice in order to derive the meaning and sources of this concept as they evolved from a debate on the subject among Muslim thinkers from generation to generation. True, justice in theory is divine by nature (as laid down in the Revelation), but I tried to indicate how its meaning in practice was at first narrow, confined to political justice: and I went on to explain how the meaning was extended to include other aspects: theological, moral, legal, social, and others...

Third, Professor Anderson uses the terms "Islamic law" and "moral law" interchangeably and, consequently, adds further confusion about the relevance of these terms to justice. It is true that Islamic law contains certain moral elements, but the two systèms-Islamic law and moral law-are not the same, since moral rules are recommen(Continued on p. 3l) 


\section{Correspondence (from p. 4)}

datory in nature and cannot be considered as binding as legal rules. She also equates Islamic law with Revelation, as if Revelation were the only source of law. It is well known to students of Islamic law that the sources are both the Revelation and Reason (the first is embodied in the Qur'an and Hadith, and the second is exercised collectively by consensus and individually by analogy). Even the Revelation, on matters of general principles, is subject to interpretation. Yet the reviewer makes the categorical remark "The orthodox consensus came to be, therefore, that the law is God's and that fidelity to the law based on the Revelation is justice, however capricious the consequences of such fidelity may sometimes seem," despite my efforts to make it clear that the ideal of divine justice was in practice defined and determined by most writers in terms based on man's experiences in society. In' other words, divine justice, as stated in the final chapter, indicates "for men the paths of right and wrong so that all, each according to his light, would pursue the right and reject the wrong in order to achieve the good in this world." Moreover, the scale of human justice is based not only on Islamic law but on the public order, which is the product of law, the creed, state acts, and the opinions of scholars on all matters arrived at through human reasoning. These, as indicated in the final chapter, are "by necessity subject to adaptation and refinement to meet changing conditions and the growing needs of the community." Without such relative flexibility no public order is expected to survive.

Finally, Professor Anderson asserts that "the procedural informality of Islamic law," which leaves room for individual discretion, is looked at askance by modem thinkers (including myself). "But Khadduri," she says, "does not make explicit an altemative position, which would require recognition of the apparent arbitrariness of certain elements of Islamic law." Contrary to her assertion, I have already made ny position clear on the matter in the last chapter of the book under review, as well as in earlier studies (see my Political Trends in the Arab World, chapters 9-10): that a nexus between Islamic law and the new concepts of law and institutions borrowed from foreign societies would be necessary if the conscience crisis were to be resolved and the minds of the public set at rest. For, if the public were opposed to an alternative position, the legitimacy of the new system would always be in question, resulting in continuing tensions and instability. The three examples of the codes of law provided in the final chapter of my book illustrate the manner in which the law can be modemized to the satisfaction of the public.

For these and other less serious matters raised in Professor Anderson's review, some of which reflect an inadequate familiarity with the literature un the subject. I do not think her review is very helpful for a deeper understanding of Islamic culture

Majid Khaddur

\section{Professor Emeritus}

School for Advanced

International Studies

The Johns Hopkins Universin

Washington, D.C.

Lisa Anderson responds:

I regret that Professor Khadduri feels I misunderstood his book, since I have long been an admirer of his work. Indeed, like many of my generation, I cut my teeth as a student in the field years ago on his very valuable studies of Islam and of politics in the Arab world. Still, while it is probably always unfair to juxtapose books of somewhat different purpose and approach in a single and necessarily short review, I nonetheless stand by my general assessment of The Islamic Conception of Justice. Perhaps my biggest reservation is about the utility of "empirical idealism" in examining a cultural tradition largely unfamiliar to the audience for which the study is intended. In emphasizing the development of ideas, all but divorced from the political, social, and economic context in which they tok shape. Professor Khadduri deprives his readers of the source and circumstances of the debates he so thoroughly describes. I do not think I quoted him out of context (and certainly regret his conclusion that I did so); in any event, I think anyone writing about ideas should make explicit his or her conception of the relationship between change in the ideological or legal spheres and that in the political, social, and oconomic realms. This is particularly desinable if, as Professor Khadduri suggests here, human reason and "the changing conditions... of the community" are held to play an important role in legal development. It is in this; fespect that I think references to "most writers" or to "ideals... defined in practice" are 100 am. biguous to be enlightening. This is a study which encompasses 1,400 years of writers and practices and a land area thal stretches between Spain and Indonesia; we must as. sume that writers and practices vaned

Moreover, I am not satisfied that merely pointing out the need for a "nexus" between Islamic and borrowed legal concepts and institutions is adequate to the task. As Professor Khaddur hiroself suggests in the book, the three codes to which he refers "have aroused intense controversy between Modernists and Revivalists." Perhaps it is too much to ask that an explicit discussion of the very different-indeed. often contradictory-foundations of Islamic and Western legal concepts and institutions be included in a book about Islamic law. None. theless, I think such a discussion would benefit both its Western readers and the Muslim thinkers now grappling with the profoundly difficult and often disturting questions posed by the prevalence of non Islamic legal practices in the Islamic world

Professor Khadduri's brief for his book is, as usual, eloquent, and it provides a good taste of his style and purposes Thus we should let it stand as an adverisement for those readers who might find his approach more congenial than I do

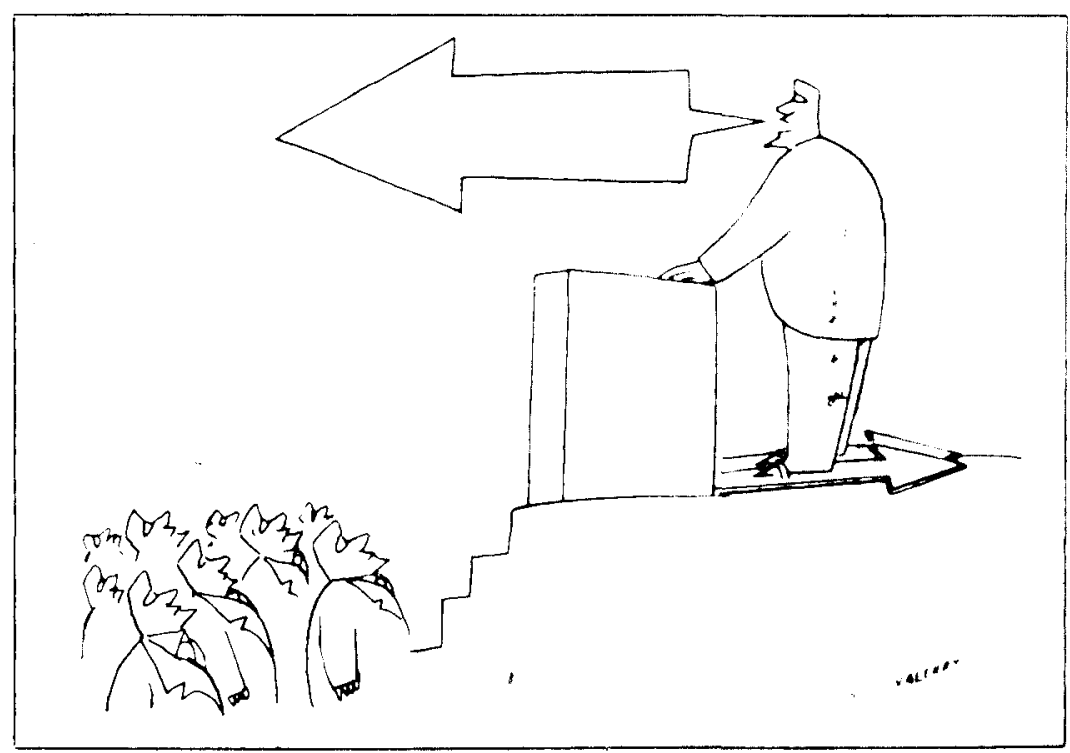

